\title{
Isolation of a mycoplasma from sarcoid tissue
}

\author{
ELLI JANSSON, MATTI HANNUKSELA, HANS EKLUND, HELENA HALME, \\ AND SIRKKA TUURI \\ From the Minerva Foundation, Institute for Medical Research, the Department of Dermatology, University \\ Central Hospital, and the Finnish Pulp and Paper Research Institute, Helsinki, Finland
}

SYNOPSIS Using a modified cell-free culture medium, a mycoplasma was isolated from sarcoid lymph nodes in two cases and from sarcoid skin lesions in four out of seven cases of chronic sarcoidosis. Growth inhibition tests showed that the isolates were related to Mycoplasma orale type 1. By the indirect haemagglutination method, 244 cases of definite or probable sarcoidosis, 160 patients with other diseases, and 355 blood donors were tested for antibodies against an isolated mycoplasma (strain $215-\mathrm{M}$ ). Titres $\geqq 16$ were found in $14 \%$ of the patients with sarcoidosis and in $8 \%$ of the patients with other diseases but only in $0.6 \%$ of the blood donors. The proportion of patients with high antibody titres among those with sarcoidosis and erythema nodosum was smaller $(8 \%)$ than among those with other forms of sarcoidosis $(17 \%)$.

The role of the mycoplasmas isolated from sarcoid tissues remains obscure, but it is possible that these organisms are only an expression of altered immunity in sarcoidosis.

The aetiology of sarcoidosis is still unsolved. Some investigators consider sarcoidosis to be a sarcoid reaction against several different agents (Kooij, and Gerritsen, 1958; Waksman, 1962; Scadding, 1967). Mankiewicz (1964), for example, was able to isolate acid-fast bacilli from sarcoid lymph nodes. Williams and Nickerson (1935) suggested virus to be the causative organism. In 1950, Löfgren and Lundbäck reported a positive virus isolation from six cases of sarcoidosis. However, two years later the authors published their further studies on attempts to isolate virus from sarcoid tissues with negative results (Lundbäck, and Löfgren, 1952). They concluded that the isolated strains were probably laboratory pick-ups of mumps virus. Recently, Hirshaut, Glade, Vieira, Ainbender, Dvorak, and Siltzbach (1970) reported elevated antibody titres against EB virus to be very common in sarcoidosis. In Finland (Nikoskelainen, Hannuksela, and Palva, 1971) and Sweden (Wahren, Carlens, Espmark, Lundbeck, Löfgren, Madar, Henle, and Henle, 1971) too the number of cases with abnormally high EB virus antibody titres has been found to be greater among sarcoid patients than among age-matched controls.

At the fifth international conference on sarcoidosis held in Prague in 1969 Homma, Okano, and Motchizuki (1971) presented their preliminary studies

Received for publication 19 July 1972. on attempts to isolate mycoplasma in sarcoidosis. From throat swabs they found unidentified mycoplasma significantly more often than in control patients. On the other hand, they did not succeed in isolating the organisms from sarcoid tissues.

We have made trials to isolate mycoplasmas from sarcoid tissues. The results of these successful attempts as well as the results of the determination of mycoplasma antibody titres by the indirect haemagglutination technique are presented here.

\section{Patients and Methods}

\section{PATIENTS}

They were examined at the Department of Dermatology, University Central Hospital, Helsinki. The diagnosis of sarcoidosis was confirmed with histological evidence of sarcoidosis and/or with a positive Kveim test. Patients with radiological evidence of sarcoidosis but for whom the diagnosis was not confirmed were classified as probable sarcoidosis.

\section{BIOPSY SPECIMENS}

These were taken under local anaesthesia. All the skin biopsy specimens were cultured immediately (within one to three hours of the operation), but the two lymph nodes were stored at $-22^{\circ} \mathrm{C}$ for three and five years, respectively, before cultivation. Kveim antigen was prepared from both lymph 
nodes. The one (case 1, Table I) was inactive but the other (case 2) was active Kveim material.

Three skin biopsies and 18 muscle biopsies taken from controls were studied in the same way as the specimens from sarcoid cases.

\section{SERUM SPECIMENS}

Using the indirect haemagglutination technique, 244 cases of definite or probable sarcoidosis, 160 patients with other diseases, and 355 blood donors were tested for antibodies against an isolated mycoplasma (strain 215-M).

\section{ISOLATION TECHNIQUE}

The medium was the solid and diphasic PPLO medium described by Marmion (1967) with the following modifications: (1) Brain-heart infusion broth was used instead of PPLO broth; for solid medium, $1 \cdot 1 \%$ agar was added to it. (2) The broth medium was further enriched with egg yolk pasteurized at $+60^{\circ} \mathrm{C}$ for 50 minutes and added in amounts of $0.1 \mathrm{ml}$ to $10 \mathrm{ml}$ of broth medium.

The biopsy specimens with some broth added were crushed in a mortar. Then a loopful of the suspension was inoculated into $3 \mathrm{ml}$ of Marmion's enriched diphasic broth medium. The cultures were incubated at $+37^{\circ} \mathrm{C}$ and subcultures were made on solid media after 10 and 20 days inoculating $0.1 \mathrm{ml}$ of the broth culture on solid medium in Petri dishes $5 \mathrm{~cm}$ in diameter. The agar plates were incubated in an anaerobic milieu $\left(90 \% \mathrm{H}_{2}\right.$ and $\left.10 \% \mathrm{CO}_{2} / \mathrm{v} / \mathrm{v}\right)$ at $+37^{\circ} \mathrm{C}$ for 10 days. Subcultures from the broth tubes were made by transferring $0.3 \mathrm{ml}$ of the culture into new broth tubes. The agar plates were examined under a high-power microscope (Leitz Orthoplan) as described earlier (Jansson, 1971).
BIOCHEMICAL, GROWTH INHIBITION, AND INDIRECT HAEMAGGLUTINATION TESTS

These have been described in detail earlier (Jansson, Mäkisara, Vainio, Snellman, and Tuuri, 1971a).

SCANNING ELECTRON MICROSCOPY

This was performed as reported earlier (Jansson, Eklund, Vainio, Halme, and Tuuri, 1971b).

\section{REFERENCE STRAINS}

M. hominis strain MJW was kindly supplied by Dr Ruth Lemcke, $M$. fermentans strain G II $\mathrm{N}$ and $M$. orale type 1 by Professor Charlotte Ruys,

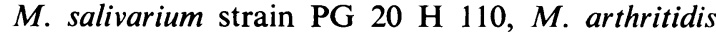
strain PG 6, and $M$. pulmonis strain Ash PG 34 by Dr R. H. Leach, and M. gallinarum by Dr T. Estola.

\section{Results}

ATTEMPTS TO ISOLATE MYCOPLASMA

An organism resembling mycoplasma was isolated from four out of seven skin biopsy specimens and from both lymph nodes examined. The cardinal symptoms and signs of the disease of these patients are presented in Table I.

Colonies resembling mycoplasma were seen in the primary culture in five cases and in the first culture passage in one case. In the primary culture, only a few mycoplasma-like colonies grew on the solid medium. In later passages, the number of the colonies increased. None of the isolates showed large, typical 'fried egg' forms with a dark centre and a light periphery. The size of the colonies was only about $1 / 10$ to $1 / 100$ of that of the large-colony mycoplasmas. However, the fragile granular structure typical of mycoplasmas was seen clearly when

\begin{tabular}{|c|c|c|c|c|c|c|c|c|c|c|c|c|c|c|c|c|c|}
\hline \multirow{3}{*}{$\begin{array}{l}\text { Patient } \\
\text { No. }\end{array}$} & \multirow{3}{*}{$\operatorname{Sex}$} & \multirow{3}{*}{$\begin{array}{l}\text { Age } \\
(y r)\end{array}$} & \multirow{3}{*}{$\begin{array}{l}\text { Duration } \\
\text { of Disease }\end{array}$} & \multicolumn{7}{|c|}{ Sarcoid Manifestations } & \multirow{2}{*}{\multicolumn{3}{|c|}{$\begin{array}{l}\text { Isolation of } \\
\text { Mycoplasma }\end{array}$}} & \multirow{3}{*}{$\begin{array}{l}\text { Indirect } \\
\text { Haemagglu- } \\
\text { tination } \\
\text { Titre against } \\
\text { Strain } 215\end{array}$} & \multicolumn{3}{|c|}{ Skin Tests } \\
\hline & & & & \multirow{2}{*}{ Lung } & \multirow{2}{*}{$\begin{array}{l}\text { Lymph } \\
\text { Node }\end{array}$} & \multirow{2}{*}{ Skin } & \multirow{2}{*}{ Liver } & \multirow{2}{*}{ Spleen } & \multirow{2}{*}{ Eyes } & \multirow{2}{*}{ Bones } & & & & & \multirow{2}{*}{ Kreim } & \multirow{2}{*}{$\begin{array}{l}\text { Man- } \\
\text { toux }\end{array}$} & \multirow{2}{*}{$\begin{array}{l}T U \text { 을 } \\
P P D\end{array}$} \\
\hline & & & & & & & & & & & Organ & Result & Strain & & & & \\
\hline 1 & $\mathbf{M}$ & 20 & $2 \mathrm{mth}$ & & & - & - & - & - & - & $\begin{array}{l}\text { Lymph } \\
\text { node }\end{array}$ &.$\cdot$ & 215-M & 8 & \pm & 100 & - \\
\hline 2 & $F$ & 53 & $6 y \mathrm{r}$ & - & & $\ldots$ & - & - & - & - & $\begin{array}{l}\text { Lymph } \\
\text { node } \\
\text { Skin }\end{array}$ & $\therefore$ & 336-M & 1024 & $\doteqdot$ & 10 & . \\
\hline 3 & $F$ & 56 & $3 \mathrm{yr}$ & . & & & - & - & - & - & Skin & - & & 32 & \pm & 100 & - \\
\hline 4 & $F$ & 45 & $11 \mathrm{mth}$ & & - & - & - & - & - & - & Skin & & 191-M & ND & $(\cdots)$ & 1 & - \\
\hline 5 & $\mathbf{F}$ & 59 & $3 \mathrm{yr}$ & & - & & - & - & - & . & Skin & & 192-M & $<8$ & - & 0.1 & - \\
\hline 6 & $F$ & 51 & $2 \mathrm{yr}$ & & - & & - & - & - & - & Skin & - & & 8 & $(-)$ & 10 & - \\
\hline 7 & $F$ & 51 & $2 \mathrm{mth}$ & . & - & .. & - & - & - & - & Skin & & $227-M$ & 32 & ND & 10 & $\therefore z$ \\
\hline 8 & $\mathbf{M}$ & 39 & $5 \mathrm{mth}$ & .. & - & - & - & - & - & - & Skin & $\cdot \cdot$ & 239-M & ND & - & 1 & $\therefore$ c \\
\hline 9.11 & Cont & ols & & & & & & & & & Skin & - & & & & & \\
\hline
\end{tabular}

Table I Isolation of mycoplasmas from sarcoid tissues

ND = not done, $\oplus=$ histological confirmation, $(-)=$ no histological confirmation.

In case 5 the hilar and lung manifestations had already disappeared at the time of the examination. 


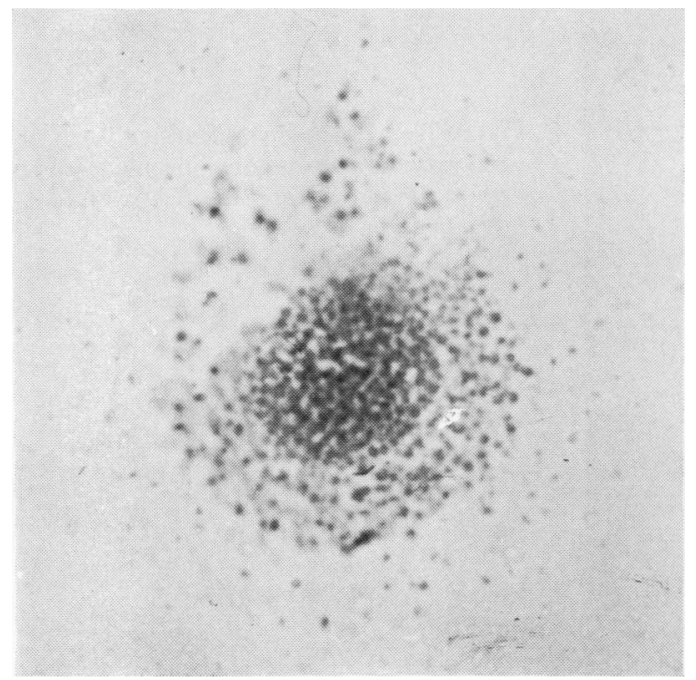

Fig. 1.

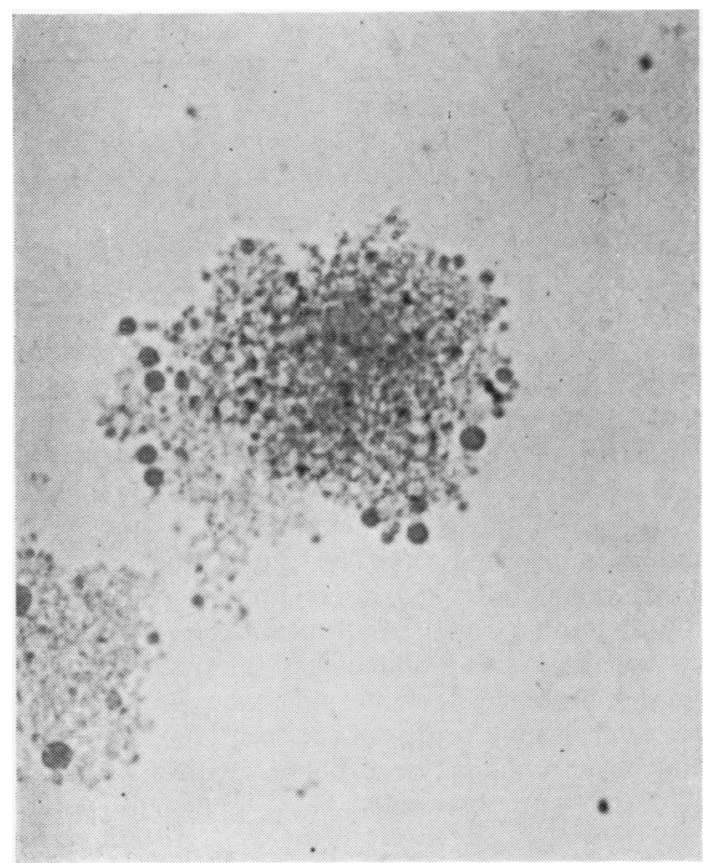

Fig. 3.

stained with Dienes stain and examined with a 1000 -fold magnification. Figures 1-3 illustrate the microscopic appearance of three different isolates.

The isolated strains did not convert to bacteria when penicillin and thallium acetate were omitted from the culture medium. They required sterol for

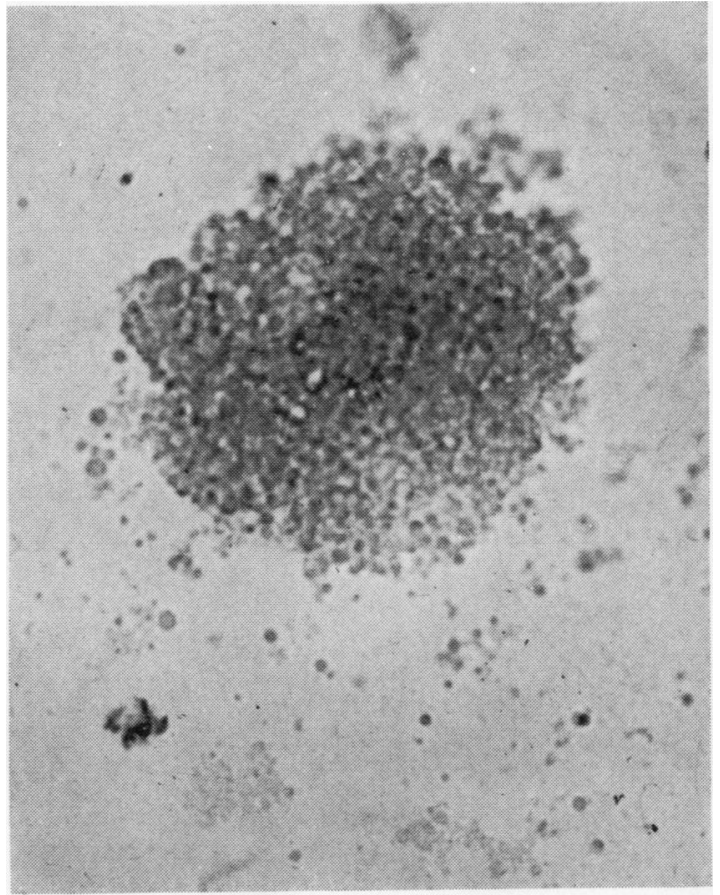

Fig. 2.

Figures 1-3 Isolates from sarcoid tissue, stained with Dienes stain and with a 1000-fold magnification.

Fig. 1 Strain 191-M, 12th passage, cultivated from a skin biopsy specimen.

Fig. 2 Strain 215-M, 8th passage, obtained from sarcoid lymph node.

Fig. 3 Strain 227-M, 8th passage, isolated from a skin biopsy specimen.

their growth. The isolates did not ferment glucose or split urea, but they were arginine positive.

Because the isolates did not form colonies visible to the naked eye antisera against five strains were prepared in rabbits. The immune sera inhibited the growth of $M$. orale type 1 with an inhibition zone 


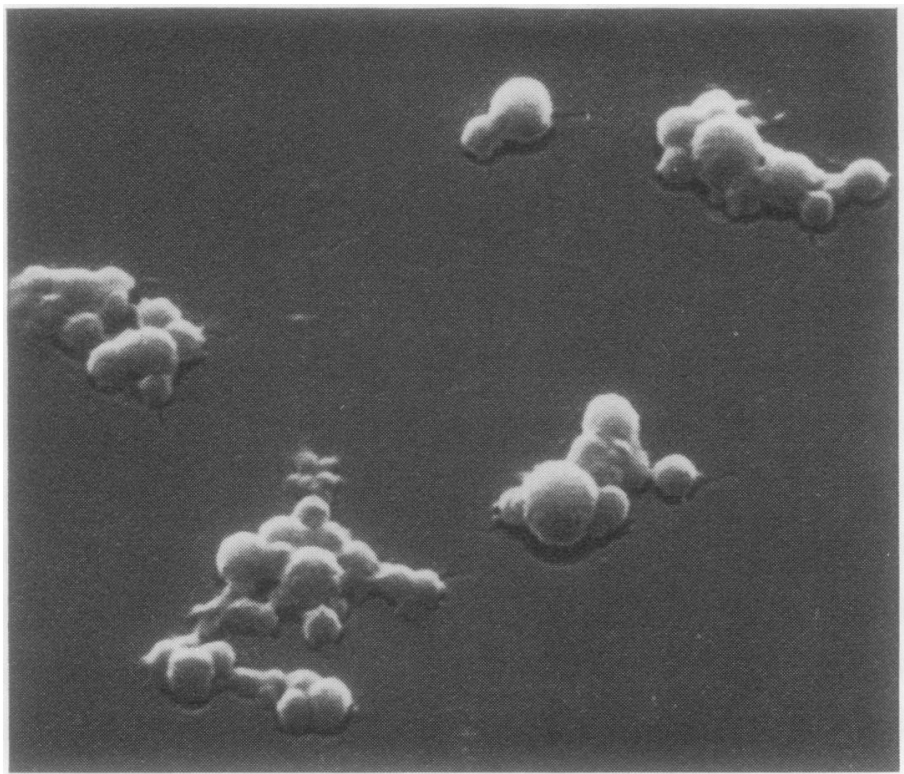

Figures 4-5 Scanning electron

micrographs of an isolate (strain 215-M) from a sarcoid lymph node, 10 000-fold magnification.

Fig. 4 Two-day growth.

Fig. 5 Ten-day growth.

\section{Fig. 4.}

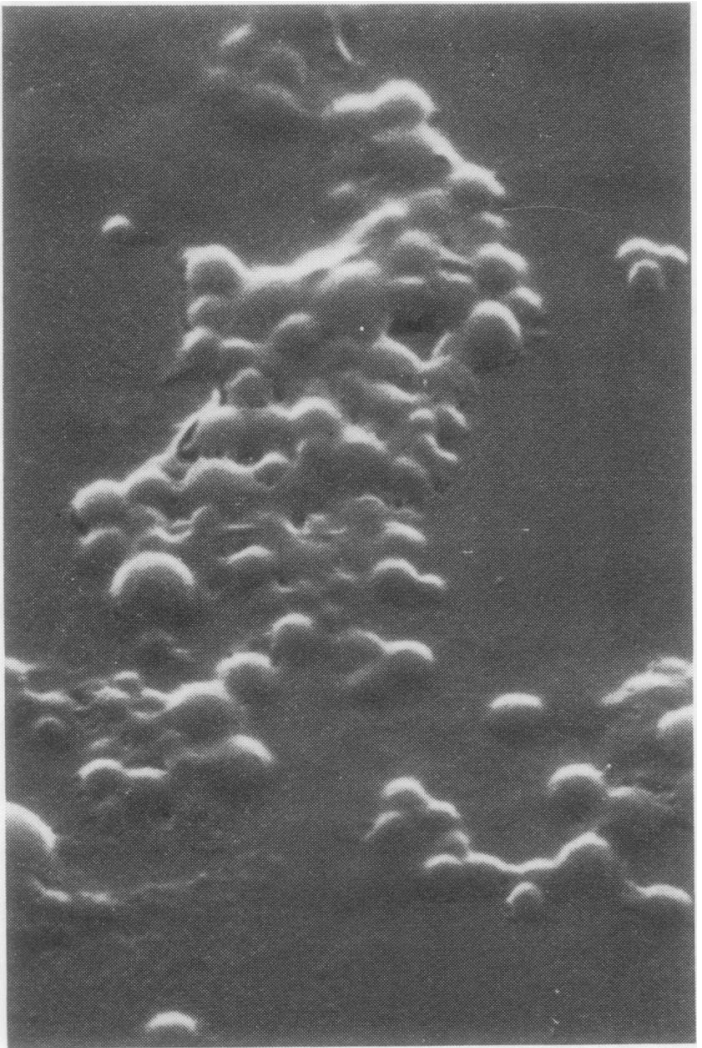

Fig. 5. of $3 \mathrm{~mm}$ which was equal to that obtained with homologous immune serum. $M$. hominis, $M$. salivarium, $M$. fermentans, $M$. pulmonis, $M$. arthritidis and $M$. gallinarum were not inhibited.

SCANNING ELECTRON MICROSCOPIC STUDIES Strain 215-M cultivated from a sarcoid lymph node was studied in the 13th culture passage on cell-free media. In the two-day broth culture small groups of spherical organisms were seen (Fig. 4). A few cells showed budding and others short and thin filaments. The size of the organisms varied from 0.5 to $1.0 \mu \mathrm{m}$. In the three-day culture larger organisms up to $1.8 \mu \mathrm{m}$ appeared. Also membranes or ghosts of them were observed. The four-day culture revealed round forms, both separately and in clusters. In addition, some very small elementary body-like cells appeared with a diameter of 0.1-0.2 $\mu \mathrm{m}$. In the 10-day culture clusters of spherical cells with distinct interplasmic bridges were seen (Fig. 5). Some elements resembling 'large bodies' with a diameter of $2.5 \mu \mathrm{m}$ were observed.

DETERMINATION OF MYCOPLASMA ANTIBODIES Using the indirect haemagglutination technique, 230 patients with definite sarcoidosis, 14 patients with probable sarcoidosis, 160 patients with other diseases, and 355 blood donors were tested for antibodies against an isolated mycoplasma (strain 215-M.) The results can be seen from Table II.

A titre of 2048 was found in five patients. One of them had acute sarcoidosis with erythema nodosum, 


\begin{tabular}{|c|c|c|c|}
\hline Group & No. of Cases & $\begin{array}{l}\text { No. with } \\
\text { Antibody Titre > } 16\end{array}$ & $\begin{array}{l}\text { Highest } \\
\text { Titre }\end{array}$ \\
\hline $\begin{array}{l}\text { Sarcoidosis } \\
\text { Subacute sarcoidosis with erythema nodosum } \\
\text { Subacute sarcoidosis without erythema nodosum } \\
\text { Chronicsarcoidosis } \\
\text { Probable sarcoidosis }\end{array}$ & $\begin{array}{r}71 \\
116 \\
43 \\
14\end{array}$ & $\begin{aligned} 5 & (7 \%) \\
20 & (17 \%) \\
7 & (16 \%) \\
2 & \end{aligned}$ & $\begin{array}{l}2048 \\
2048 \\
2048 \\
2048\end{array}$ \\
\hline Total & 244 & $34(14 \%)$ & 2048 \\
\hline $\begin{array}{l}\text { Patients with other diseases } \\
\text { Non-sarcoid erythema nodosum } \\
\text { Tuberculosis } \\
\text { Collagenoses } \\
\text { Granulomatosis disciformis Miescher } \\
\text { Malignancies } \\
\text { Tularaemia } \\
\text { Other diseases }\end{array}$ & $\begin{array}{r}49 \\
34 \\
6 \\
6 \\
4 \\
1 \\
60\end{array}$ & $\begin{array}{l}4(8 \%) \\
1 \\
1 \\
2 \\
1 \\
1 \\
3(5 \%)\end{array}$ & $\begin{array}{r}128 \\
32 \\
32 \\
256 \\
2048 \\
128 \\
64\end{array}$ \\
\hline Total & 160 & $13(8 \%)$ & 2048 \\
\hline Blood donors & 355 & $2(0.6 \%)$ & 16 \\
\hline
\end{tabular}

Table II Antibody titres (IHA) against strain 215-M obtained from a sarcoid lymph node in the sera of patients with sarcoidosis and of controls

another had a very acute form of the disease but without erythema nodosum, one had chronic smouldering sarcoidosis with pulmonary manifestations, one had probable pulmonary sarcoidosis, and one patient had acute lymphatic leukaemia with a fatal outcome.

As a group, the patients with sarcoidosis showed higher indirect haemagglutination titres against the isolate 215-M than the others. The proportion of patients with elevated antibody titres among those with sarcoidosis and erythema nodosum was smaller $(8 \%)$ than among those with other forms of sarcoidosis $(17 \%)$.

The patients in the control group suffered from various diseases which were treated in the Department of Dermatology. The most usual diagnoses were: different forms of panniculitis on the legs (other than erythema nodosum), psoriatic eczema, granulomatosis disciformis Miescher, collagen diseases, urticaria, and erythema exudativum multiforme. The patients with Miescher's disease, malignancies, and collagenoses showed elevated mycoplasma antibody titres against the isolate 215-M more often than the rest in this control group.

\section{Discussion}

Mycoplasma was isolated from two sarcoid lymph nodes and four skin biopsy specimens. Growth inhibition tests showed them to be related to $M$. orale type 1 . This mycoplasma was found in the throat in $25 \%$ of healthy persons (Taylor-Robinson, Canchola, Fox, and Chanock, 1964). The possibility that the isolated strains were laboratory pick-ups was small because there was no growth from the skin biopsy specimens of the controls or from muscle biopsies of the non-sarcoid patients. More- over, $M$. orale type 1 reference strain was not handled in the laboratory during this study. $M$. gallinarum and $M$. gallisepticum, mycoplasmas occurring occasionally in hen's eggs, were not found as contaminants during this investigation. Thus, it seems probable that a mycoplasma related to $M$. orale type 1 is fairly often found in sarcoid tissue.

The significance of this organism in the pathogenesis of sarcoidosis is obscure. Further studies on its occurrence in sarcoidosis and its pathogenicity are needed to resolve whether it is the cause of sarcoidosis or not. It is possible that mycoplasma found in sarcoid tissues is able to survive there due to altered immunity in this disease. Also it may be that the organism increases in number in sarcoidosis and other chronic diseases such as collagen diseases and malignancies (see Table II), influencing humoral and/or cellular immunity. That the antibody titres were higher in chronic sarcoidosis than in incipient sarcoidosis with erythema nodosum speaks in favour of this suggestion.

This study was supported by a grant from the Sigrid Jusélius Foundation.

\section{References}

Hirshaut, Y., Glade, P., Vieira, L. O. B.D., Ainbender, E., Dvorak, B., and Siltzbach, L. E. (1970). Sarcoidosis, another disease associated with serologic evidence for herpes-like virus infection. New Engl. J. Med., 283, 502-506.

Homma, H., Okano, H., and Motchizuki, H. (1971). An attempt to isolate mycoplasmas from patients with sarcoidosis. In Proceedings of the Fifth International Conference on Sarcoidosis, edited by $L$. Levinský and F. Macholda, p. 101. Karlova University Press, Prague.

Jansson, E. (1971). Isolation of fastidious mycoplasma from human sources. J. clin. Path., 24, 53-56.

Jansson, E., Mäkisara, P., Vainio, K., Snellman, O., and Tuuri, S. (1971a). Further studies on mycoplasma in rheumatoid arthritis. Acta rheum. scand., 17, 227-235. 
Jansson, E., Eklund, H., Vainio, K., Halme, H., and Tuuri, S. (1971b). Scanning-beam electron microscopy of mycoplasma isolated from rheumatoid arthritis. J. clin. Path., 24, 808-809.

Kooij, R., and Gerritsen, T. (1958). On the nature of the Mitsuda and the Kveim reaction. Dermatologica (Basel), 116, 1-27.

Lundbäck, H., and Löfgren, S. (1952). Attempts at isolation of virus strains from cases of sarcoidosis and malignant lymphoma. Acta med. scand., 143, 98-109.

Löfgren, S., and Lundbäck, H. (1950). Isolation of a virus from six cases of sarcoidosis. Acta med. scand., 138, $71-75$

Mankiewicz, E. (1964). The relationship of sarcoidosis to anonymous bacteria. Acta med. scand., Suppl., 425, 68-73.

Marmion, B. P. (1967). The mycoplasmas: new information on their properties and their pathogenicity for man. In Recent Advances in Medical Microbiology, edited by A. P. Waterson, pp. 170-253. Churchill, London.
Nikoskelainen, J., Hannuksela, M., and Palva, T. (1971). Fluorescent antibodies to EB (Epstein-Barr)-virus in sarcoidosis. (Atstr.) Scand. J. Lab. Invest., 27, Suppl. 116, 49.

Scadding, J. G. (1967). Sarcoidosis, pp. 489-490. Eyre and Spottiswoode, London.

Taylor-Robinson, D., Canchola, J., Fox, H., and Cha nock, R. M. (1964). A newly identified oral mycoplasma $(M$. orale $)$ and its relationship to other human'mycoplasmas. Amer. J. Hyg., 80 , 135-148.

Wahren, B., Carlens, E., Espmark, Å., Lundbäck, H., Löfgren, S. Madar, E., Henle, G., and Henle, W. (1971). Antibodies to various herpesviruses in sera from patients with sarcoidosis. $J$. nat. Cancer Inst., 47, 747-755.

Waksman, B. H. (1962). Auto-immunization and the lesions of autoimmunity. Medicine (Baltimore), 41, 93-141.

Williams, R. H., and Nickerson, D. A. (1935). Skin reactions in sarcoid. Proc. Soc. exp. Biol. (N.Y.). 33, 403-405. 